\title{
The Relationship between Foreign Trade and Financial Performance of the Listed Manufacturing Companies in Nigeria
}

\author{
Yakubu Yahaya ${ }^{1}$, Dr. Oloko Magret $A^{2}$, Dr. Oluoch Oluoch ${ }^{3}$ \\ ${ }^{1}$ Department of Business Administration, School of Business, Jomo Kenyatta University of Agriculture and \\ Technology, Kenya \\ ${ }^{2,3}$ Department of Business Administration, School of Business, Jomo Kenyatta University of Agriculture and \\ Technology, Kenya
}

\begin{abstract}
The main objective of this study was to determine the relationship between foreign trade and financial performance of the listed manufacturing companies in Nigeria. The study focused on the 32 listed companies randomly drawn from the 74 listed manufacturing companies in Nigeria. The secondary data extracted from the financial statement of these companies were subjected to both descriptive and inferential statistics. The result shows a significant positive relationship between the two variables. It was therefore recommended that the management and the board of directors of the listed manufacturing companies should intensify efforts on how the locally produced products will be able to penetrate into the foreign countries as it was discovered that majority of the goods produced by the manufacturing companies in Nigeria are consumed locally
\end{abstract}

Keywords: Foreign Trade, Financial Performance, Internationalization, Return on Assets

\section{Introduction}

A firm's decision to expand operations to international markets has far reaching implications that can shape operations for many years and impact its future profitability and growth opportunities (Altuntas \& BerryStölzle, 2010). The internationalisation of company which is otherwise known as foreign trade means that its activities go beyond the boundaries of its home country, or are undertaken chiefly abroad. Such a company operates either both in its domestic and foreign market, or only in the latter one. Foreign trade is equated with a company's foreign expansion, which may comprise of any kind of business activity undertaken abroad or with a foreign partner (Wach, 2014).

According to Johanson and Mattsson (2015) company internationalization (regardless of adopted strategy of performing this process) requires obtaining capital, a competent manager, choosing appropriate product offer, then analysing the target market (analysis of foreign markets), entering the foreign market (canvassing, sales, marketing) and developing operations (logistics, after-sales service, realization of payments, responsibility for sold products, intercultural communication in a team of employees). Each enterprise develops its own strategy for foreign trade and in accordance with the adopted strategy it must provide a set of factors vital for the foreign trade process and individually establish the level of these factors.

The decision to embark on foreign trade by firms has generated interest in many stakeholders not just because of the benefits to firm growth, survival and competitive position, but also because of its positive influence on a nation's economic growth and development (Mayer \& Ottaviano, 2008). However, while foreign trade can be a source of growth for firms, it can also be a risky venture that can generate losses which may adversely affect the long term survival of a firm. Any company seeking to be an industry leader in the twentyfirst century must not focus on domestic market leadership only, but must also focus on global market leadership. O'Cass and Weerawardena (2009) justified that global competition for African businesses is not an option but an economic priority.International expansion can enhance a firm's knowledge base and capabilities through the experiential learning it gets from operating in foreign markets. Industrial organization arguments have also been used to postulate that firms can gain greater market power over suppliers, distributors, and customers by expanding overseas. Some researchers have suggested that firms can diversify risks by operating across several international markets (Crick, 2009). The benefits from the exploitation of economies of scale and scope, organizational learning through exploration and greater market power implies that firms with greater international diversification should experience higher financial performance.

Although as firms operate in more diverse market environments, they face a greater need to integrate their activities and logically encounter an escalation in the cost of coordinating their activities. At higher levels of international expansion, diseconomies can set in due to escalating costs of coordination and from the greater information processing demands on managers and administrative systems. With continued international 
diversification, the complexities of managing information and communication among widespread units imply that extensive international diversification is likely to result in net costs (Ellis, 2007). The increasing economic integration of markets associated with globalization has not only driven the internationalisation of companies, it has also influenced the nature of their strategies. Technological change and the ease of trade have enabled managers to effectively monitor and control their company's global activities and have resulted in major changes in organizational relationship and strategy. While historically many companies have had foreign sales operations, the ability to conduct business efficiently and effectively across the boundaries has enabled managers to make strategic decisions on where to geographically locate the different activities that constitute a firm's value chain (Melén \& Nordman, 2009). The current decline in the financial performance of many notable companies necessitated this study. The rest of the paper is as follow. Section 2 deals with the review of empirical literature. The methodology adopted in this study was expatiated in section three. The presentation of data and data analysis was done in section 4 while the summary and conclusion was done in section 5.

\subsection{Theoretical Review: Internalization Theory}

\section{Review Of Literature}

This theory was developed by Buckley and Casson (1976) and followed by Hennart (1982). The origin of this theory was by Coase (1937) in a national context and Hymer (1976) in an international context. Hymer (1976) established two major determinants of FDI. The first were the advantages, which some firms possess in a particular activity while the second was the removal of competition. Buckley and Casson 1976) state that transnational companies organize their internal activities to benefit from specific advantages, which are to be exploited. The Internalization theory lies on why companies do not prefer to sign contract with a subcontractor in a foreign country instead of engaging in Foreign Direct Investment themselves. Denisia (2010) illustrates Internalization theory on the concept that transnational companies arrange their activities internally to achieve specific advantages that they can exploit. This theory explains the growth of multinational enterprise (MNE) and the reasons why countries venture into foreign direct investment. If companies contract out with a subcontractor, such companies may use the technology to compete with the agency company by interrupting the contract or the agent may damage the brand reputation of the company. Hymer (1976) demonstrates that FDI take place, only if the benefits of exploiting these specific advantages are more than the cost of the operations in foreign country. Most companies are more comfortable with investing directly in a foreign country. It must be more beneficial to the firm possessing the ownership advantages to use them itself rather to lease or sell them to foreign firms.

Hymer (1976) discussed the problem of information costs for international firms with respect to local firms, different currency risk and differences in government's fiscal policies. The theory of internalisation explains the motivations of the transnational companies for making foreign direct investment by taking advantage of various government fiscal policies and other policies. The internalisation advantages include the following: avoid governmental intervention such as tariffs, price controls and quotas; avoidance of litigation and violated contract; control of conditions and supply of sale of inputs; application of transfer pricing; avoidance of negotiation and search costs and control of market outlets.

The possession of internalization advantages suggests that the firm will exploit these advantages by way of FDI rather than by contractual resource exchanges. For the purpose of this study, internalisation theory is found relevant as it provides theoretical foundation for explaining how companies can internally organise the organisation's system to benefit from internationalisation and its effect on financial performance. Therefore, this theory is expected to provide theoretical basis for specific objective one to four.

\subsection{Empirical Review: Foreign Trade and Financial Performance}

Evidence from literature on foreign trade shows contrary positions. Foreign trade is a variable that provides information on the firms' orientation to export, and is measured as export income ratio and import expenses ratio (Filatotchev \& Piesse, 2009). Riding, Orser, Spence and Belanger (2012) study the relationship between export barriers and the export performance of Greek firms, the study used exploratory and confirmatory factor analyses. The result shows operational dimension, environmental dimension, financial dimension, source dimension has positive effect while legal dimension and logistic dimension have negative effect on performance of Greek firms.

Also, Musuva (2013) research on the firm level factors and international performance of companies listed on the Nairobi Securities Exchange. Specifically, the research focused on the effect of institutional capital, management characteristics, organisational demographics, firm capabilities, internationalisation orientation and degree of internationalisation on firm international performance. The firm capabilities studied were organisational innovation, knowledge capability and adaptive capability. This research adopted a quantitative approach based on a cross-sectional study of publicly quoted companies in Kenya. A semi structured questionnaire was administered for data collection. Structural equation modelling - Partial Least Squares analysis was used to analyse the survey responses and to test the hypotheses, however the results are still mixed. 
In addition, Ghanatabadi, (2005) conducted a study on internationalisation of small and medium-sized enterprises in Iran, based on Innovation-Related Internationalisation models the author view the development of export activities as an innovation adoption cycle or as an export development 'learning curve' influenced by internal factors. He further argues that internationalisation models explain the firms' internationalisation' in a slow and incremental manner. Kraśnicka and Głód (2013) conducted a study on the impact of the internationalisation of Polish SMEs on their performance. The study also reviewed the differences between classical models of internationalisation and the so-called born global models. The finding reveals a positive relationship between exports of small and medium enterprises and their financial performance.

Similarly, Thériault and Beckman (2008) investigate the internationalisation of Indian firms in order to identify strategic issues and organizational design. Hypotheses and study questions were developed, which were finally tested via a grounded methodology and the findings show that simultaneous to the opening up of the Indian economy to international markets, lead Indian companies to undergone significant transformation towards newer forms of organizing over the last 5 years. In addition, the findings shed light on key strategic issues such as internationalisation-related modes, competitive drivers, geographical focus, and aspirations, as well as drivers of organizational transformation of internationalizing Indian companies.

Ahmed Sheikh and Wang (2011) examine the determinants of textile and clothing exports of Pakistan, using a time series data over the period twenty years. The demand and supply side exports equation were estimated in a simultaneous equation frame-work. The coefficient on the price of textile exports and world income appeared with correct signs but turned out to be insignificant. All the coefficients on the supply side were found to be statistically significant. Ehinomen and Daniel (2012) examine the export and economic growth in Nigeria, the study uses annual time series covering 1970 to 2010 to determine the causal and long-run relationship. The findings show a uni- directional relationship between export and economic growth, thus export sales have effect on financial performance on manufacturing companies in Nigeria. Also in Pakistan Raheman, Afza, Qayyum and Bodla (2010) found that trade openness and export of sales have significant influence of performance of listed manufacturing companies.

Roy (2007) estimates the demand and supply functions of the manufactured exports for India, using a time series data over the period 1960-2006. The FIML has been used to estimate the demand and supply side exports for six different categories of manufactured exports including cloth and garments, chemicals and machinery, transport equipments, steel and iron, and the leather manufactures. The findings suggest importance of all demand side factors for exports performance. On the supply side, the variables produced mix results in terms of significance and some variables like world GDP and exports volume turned out to be insignificant for textile and iron-steel exports respectively.

Ehinomen (2012) investigates the relationship between firm performance and internationalisation behaviour for the period from the firms' start-up until 1997, using data from the first survey. They found that an international engagement improves labour productivity and increases sales growth rate, but does not affect employment growth rate. The foreign market may be particularly important for young, small, technology oriented firms, especially for those operating in a narrow market niche. In order to be competitive in international markets, Malaysian companies have taken the opportunities which are available worldwide through internationalisation strategies where there are no transactional or geographical boundaries, where business transaction can now be performed more rapidly (Molla, \& Licker, 2005).

Martinez (2006) examines the relationship between industrial districts and the export performance of SMEs in Spain using panel data. The study showed a positive and significant link between the location of the firm in the district and networks (competitors' network and institutional network) and the EP of Spanish SMEs in a given area. Indeed, according to the location of the firm in the district (near ports, airports and supplier) a company does gain because it will benefit from better conditions than its competitors. Furthermore, Damoah (2011) examine export behaviour of small and medium-sized manufacturing firms in Ghana, data were collected from garment and textile industry of Ghana. The study drew on a set of quantitative data and more qualitative interviews concerns the behaviour of both small and medium-sized exporting and non-exporting firms from the garment and textile manufacturing sector in Ghana. The findings reveal that on overall, firm size, sector, workforce education levels, and participation in international and domestic business networks are found to be the key drivers explaining why some SMEs from Ghana choose to export. Based on the findings it is concluded that international networks serves as a means of improving their financial performance through international markets.

\subsection{Research Design}

\section{Research Methodology}

This study will use both descriptive and quantitative research design; Orodho (2003) defines research design as the scheme outline or plan that is used to generate answers to research problems. Maxwell (2012) stated that descriptive research design is useful when the researcher objectives include determining the degree to 
which one variable (dependent) affect the other variable (independent). This research design will be selected for the reasons that, firstly, it helps establish the effect of foreign trade on financial performance. Secondly, it will help to achieve the main objective of this research which is focusing on effect of foreign trade on financial performance of listed manufacturing companies over a prescribed ten one-year period from January 2006 to December 2015. The quantitative portion will involve the use of multiple regressions, $\mathrm{t}$ test, correlation and diagnostic test.

\subsection{Population}

Burns and Grove (2003) describe population as all the elements that meet the criteria for inclusion in a study. A population is defined as total collection of elements about which we wish to make some inferences (Cooper \& Schinder, 2011). Mcmillian and Schumacher (2010) define population as a large collection of subjects from where a sample can be drawn. In other words, population is the aggregate of all that conforms to a given specification. The population of this study is all the listed 74 manufacturing companies in Nigeria from where a sample of 32 companies were drawn. Kitchenham and Pfleeger (2002) assert that a target population is the group of individuals to whom the survey applies. It is the collection of individuals about whom conclusions and inferences are made (Enarson, Kennedy \& Miller, 2004).Mugenda and Mugnda (2004) term target population as that population to which a researcher wants to generalize the results of the study. The study's target population is 74 seventy-four listed manufacturing companies in Nigeria.

\subsection{Data Collection Instruments}

This study will use secondary methods of data collection. The secondary data will be collected through the company's financial reports of the listed manufacturing companies in order to inquire about internationalisation and financial performance of listed manufacturing companies.

\subsection{Data processing and analysis}

Data analysis is the process of data to make meaningful information (Saunders, Lewis \& Thornhill, 2009) defined data as mechanism for reducing and organizing data to produce findings that require interpretation by researcher. According to Hyndman (2008) data processing involves translating the answers on a questionnaire into a form that can be manipulated to produce statistics. This involves coding, editing, data entry, and monitoring the whole data processing procedure. Data collected will be analyzed by editing, coding and categorizing through the use of statistical package for social sciences (SPSS) version 20.0 computer software. Descriptive and inferential statistics will be use to analyze and interpret the data use in this research. Specifically, descriptive statistics related to means and standard deviation. Inferential statistics included correlation and regression analysis.

\subsubsection{Model Specification}

With regression analysis, the study will assess the effects of independent variable on the dependent variable. The Univariate regression model is as laid below as the Equation shows the linear regression model of the independent variable against the dependent variable.

$\mathrm{Y}=\beta_{0}+\beta_{1}\left(\mathrm{FT}_{\mathrm{t}}\right)+e$

Where:

$\mathrm{Y}=$ Financial performance this will be both ROA and

$\mathrm{X}_{1}=$ Foreign Trade (export income ratio and import expense ratio)

$\beta_{0}=$ regression output constant

$\beta_{1}=$ the coefficient of independent variable

$e=$ Error Term

\section{Data Presentation and Analysis \\ 4.1 Descriptive Statistics}

In table 4.5, the descriptive statistics for the dependent variable (return on assets) and independent variables (foreign trade, foreign direct investment, research and development and foreign funding) were presented for a sample of 32 companies considered in this study. The descriptive statistics include the mean, standard deviation, minimum, maximum, sum and the number of observation. The foreign trade which is a measure of export income ratio ranges from 7\% to 36\% with a mean score of 19.1963 and standard deviation of 13.9058. The result implies that majority of the goods produced by the manufacturing companies in Nigeria are consumed locally. It can also be inferred that the level of exportation varies widely across the manufacturing sector in Nigeria which led to a standard deviation of about $13 \%$. As touching the return on assets, the mean was $0.8466 \%$ while the minimum and maximum are $0.6 \%$ and $13.53 \%$ respectively. Although a very wide variation was observed in the reported return on assets of manufacturing companies in Nigeria, but this is not 
unacceptable since both large and small firms were included in the sample. The results was consistent with those of Mitton (2002) who reported a mean score of $0.68 \%$ for return on assets and Macauley and Randoy, (2013) whose mean score for return on assets was $0.99 \%$. The results can be found in table 4.5

Table 4.1 Summary Statistics for Dependent and Independent Variables

\begin{tabular}{|c|c|c|c|c|c|c|c|}
\hline & Mean & Std. Dev & Min. & Max. & Sum & No of Obs. & \\
\hline Foreign Trade & & 19.1963 & 13.9058 & 7 & 36 & 6162 & 320 \\
\hline Return on Assets & & 0.8466 & 4.0825 & 0.62 & 13.53 & 271.76 & 320 \\
\hline
\end{tabular}

\subsection{Trend Analysis}

\subsubsection{Trend Analysis for Foreign Trade}

From figure 4.3, result of the trend analysis for the foreign trade revealed a serious fluctuation across the years. For instance, the mean of the 32 selected companies rose from 13.65 in the year 2005 to 14.98 in 2007. This implies a steady increase in the level of exportation of the locally made product by the Nigeria manufacturing companies. A slight decrease was observed between 2008 and 2009. The trend however recorded a significant increase between 2013 and 2014. The slight decrease between 2008 and 2009 can be attributed to the spillover effect of the global economic recession of 2007. However, the macroeconomic policies put in place by the government might be responsible for the rise in subsequent years.

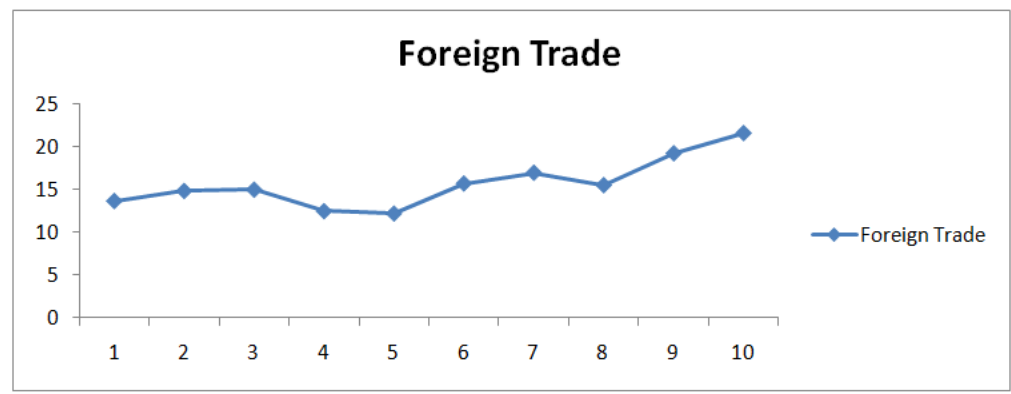

Figure 4.1: Trend Analysis for Foreign Trade

\subsubsection{Trend Analysis for Return on Assets}

The results of trend analysis for return on assets witnessed a significant increase across the years under consideration expect 2012 a little reduction from the previous year. For instance, return on assets was about $2 \%$ in 2005 whereas it was about $14 \%$ in 2014 indicating that management of the listed manufacturing companies in Nigeria have been efficient in the use of shareholders resources and thereby providing reasonable returns on the assets. The fall in 2012 can however be attributed to the economic reform that took place in 2011 among which was the mandatory implementation of international financial reporting standard (IFRS) which took place in 2011.

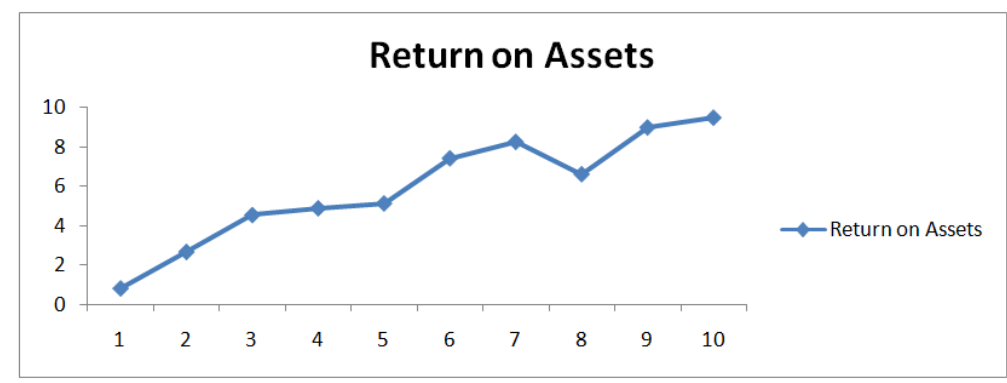

Figure 4.2: Trend Analysis for Return on Assets

\subsection{Inferential Statistics}

\subsubsection{Correlation Analysis: Pearson Correlation Analysis for Foreign Trade and Return on Assets}

The Pearson correlation of foreign trade and return on assets was computed with the use of statistical package for social sciences (SPSS version 20) and the result produces a coefficient of $0.565(\mathrm{p}$-value $=0.022)$ indicating a strong significant and positive relationship between the two variables. The result concurs with that of Caleb (2008) reported a positive relationship between foreign trade and Tobin's Q in a sample of 8,165 firms with observations from 1992 to 2001 in the US. Similarly, Wang (2012) uses panel data from 1,618 firms from 
1992 to 2004 to investigate the relationship between foreign trade and financial performance using profitability as a measure of performance. Wang (2012) finds a significant relationship between foreign trade and financial performance. From table 4.2, it can then be concluded that there is a significant linear relationship between the foreign trade and financial performance on listed manufacturing companies in Nigeria since the correlation coefficient is ranging between 0.3 and +0.7 in line with Dancey and Reidy's (2004) categorization of strength of correlation coefficient.

Table 4.2: Correlation Results for Foreign Trade and ROA

\begin{tabular}{|l|l|l|l|}
\hline \multirow{2}{*}{ ROA } & Pearson Correlation & ROA & Foreign Trade \\
\cline { 2 - 4 } & Sig. (2-tailed) & 1 & .565 \\
\cline { 2 - 4 } & $\mathrm{N}$ & 319 & .022 \\
\hline Foreign Trade & Pearson Correlation & .565 & 319 \\
\cline { 2 - 4 } & Sig. (2-tailed) & .022 & \\
\cline { 2 - 4 } & $\mathrm{N}$ & 319 & 319 \\
\hline
\end{tabular}

\subsubsection{Regression Analysis: Univariate Regression Analysis between Foreign Trade and Return on Assets}

In order to establish the statistical significance of the independent variable (foreign trade) on the dependent variable (return on assets), regression analysis was carried out. The result of the regression analysis as presented in table 4.3 revealed that $R=0.565$ and $R^{2}=0.319$. This implies that $32 \%$ of the variation in financial performance can be explained by a unit change in foreign trade. The remaining $68 \%$ of the variation can be explained by other variables such as foreign direct investment, research and development and foreign funding.

Table 4.3 Model Summary for Foreign Trade and ROA

a. Predictors: (Constant), Foreign Trade

\begin{tabular}{|l|l|}
\hline $\mathrm{R}$ & R Square \\
\hline $.565^{\mathrm{a}}$ & .319 \\
\hline
\end{tabular}

Furthermore, F-test was carried out to test the null hypothesis that there is no significant relationship between foreign trade and return on assets. The analysis of variance test in Table 4.4 shows that the significance of the F-statistic 0.000 is less than the table value of 0.05 meaning that null hypothesis is rejected and can be concluded that there is a significant relationship between foreign trade and company's return on assets. It can also be concluded that the model $\mathrm{Y}=3.055+1.568 \mathrm{X}_{1}$ is significantly fit.

Table 4.4 ANOVA Results for Foreign Trade versus ROA

\begin{tabular}{|l|l|l|l|l|l|l|}
\hline \multicolumn{1}{|c|}{} & Sum of Squares & Df & Mean Square & F & Sig. \\
\hline & Regression & 1584.576 & 1 & 1584.576 & 233.437 & $.000^{\mathrm{b}}$ \\
\cline { 2 - 7 } & Residual & 2158.584 & 318 & 6.788 & & \\
\cline { 2 - 6 } & Total & 3743.162 & 319 & & & \\
\hline
\end{tabular}

To test the significance of regression relationship between the foreign trade and return on assets, the regression coefficient $(\beta)$ and the intercept $(\alpha)$, in the model were subjected to the t-test to test the null hypothesis that the beta is zero. The null hypothesis state that, $\beta$ (beta) $=0$, meaning there is no significant relationship between the foreign trade and financial performance as the slope $\beta$ (beta) $=0$ (no relationship between the two variables). The results on the beta coefficient of the resulting model in table 4.5 revealed that the constant $\alpha=3.055$ which is significantly different from 0 , while the $\mathrm{p}$ - value $=0.000$ which is less than 0.05 . The coefficient $\beta=1.568$ is also significantly different from 0 with a $\mathrm{p}$-value $=0.000$ which is also less than 0.05 indicating that financial performance of listed manufacturing companies in Nigeria was significantly influenced by the foreign trade. This implies that the null hypothesis $\beta_{1}=0$ is rejected and the alternative hypothesis $\beta_{1} \neq 0$ is taken to hold implying that the model $\mathrm{Y}=3.055+1.568$ (Foreign Trade) is significantly fit. The model Return on assets $=\alpha+\beta$ (Foreign Trade) holds as suggested by the above test. This confirms that there is a significant positive linear relationship between the foreign trade and company's return on assets.

Table 4.5 Coefficient for Foreign Trade and ROA

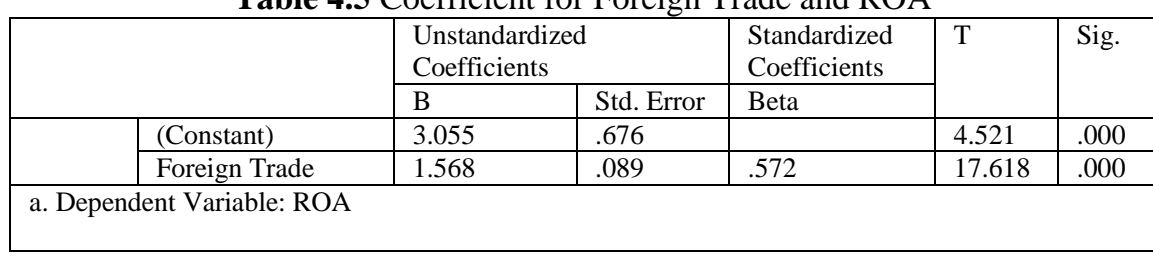


The results confirm those of Francis and Magnus (2007) on the 47 listed firms on the US stock market which revealed that firms with higher income from exportation performed better than their other counterparts and reported higher returns on assets. The study focused on 47 US firms that major in gas and computer industries using data from 1982 to 2002. This implies that the higher the income from the exportation of local products from the manufacturing companies in Nigeria the better the return on assets. The result however contradicts that of Kraśnicka and Głód (2013) who conducted a study on the impact of the internationalization of Polish SMEs on their performance. The study also reviewed the differences between classical models of internationalization and the so-called born global models. The finding reveals a negative relationship between exports income of small and medium enterprises and their financial performance.

\section{Conclusion}

The main objective of this study was to examine the effect of foreign trade on the financial performance of listed manufacturing companies in Nigeria. The study adopted the use of both descriptive and inferential statistics in ascertaining this relationship. The descriptive statistics adopted includes the mean, standard deviation, minimum, maximum and sum total while the inferential statistics includes correlation and regression analysis. The trend analysis was also carried out on all the variables in order to determine the behavior of those variables across the study period.

The descriptive results of this study revealed that foreign trade which is a measure of export income ratio ranges from $7 \%$ to $36 \%$ with a mean score of 19.1963 and standard deviation of 13.9058 . The result implies that majority of the goods produced by the manufacturing companies in Nigeria are consumed locally. It can also be inferred that the level of exportation varies widely across the manufacturing sector in Nigeria which led to a standard deviation of about $13 \%$. The correlation results on the other hand indicates that there existed a strong and significant association between foreign trade and financial performance $(r=0.565, p=0.000)$. The results of ANOVA test showed that the $F$ value is 233.427 with a significance of $p$ value $=0.000$ which was less than 0.05 , meaning that null hypothesis is rejected and conclude that there is a relationship between foreign trade and financial performance of listed manufacturing companies in Nigeria. Furthermore, the coefficient $\beta=$ 1.568 was also significantly different from 0 with a $p$-value $=0.000$ which was less than 0.05 . The result implies that a unit change in foreign trade will result in 1.568 unit change in financial performance. This confirms that there is a significant positive linear relationship between foreign trade and financial performance of listed manufacturing companies in Nigeria.

It is therefore recommended that the management and the board of directors of the listed manufacturing companies should intensify efforts on how the locally produced products will be able to penetrate into the foreign countries as it was discovered that majority of the goods produced by the manufacturing companies in Nigeria are consumed locally. Any company seeking to be an industry leader in the twenty-first century must not focus on domestic market leadership only, but must also focus on global market leadership

\section{References}

[1]. Adenikinju, A. F., \&Chete, L. N. (2002). Productivity, market structure and trade liberalization in Nigeria (Vol. 126). Nairobi: African Economic Research Consortium.

[2]. Ahmed Sheikh, N., \& Wang, Z. (2011). Determinants of capital structure: An empirical study of firms in manufacturing industry of Pakistan. Managerial Finance, 37(2), 117-133.

[3]. Alguacil, M., Cuadros, A., \& Orts, V. (2011). Inward FDI and growth: The role of macroeconomic and institutional environment. Journal of Policy Modeling, 33(3), 481-496.

[4]. Alonso-Borrego, C., \& Forcadell, F. J. (2010).Related diversification and R\&D intensity dynamics. Research Policy, 39(4), 537548 .

[5]. Anfofum, A. A., Gambo, J. S., \& Suleiman, T. (2013).Estimating the Impact of Foreign Direct Investment in Nigeria. International Journal of Humanities and Social Science, 3(17), 138-145.

[6]. Aras, G., Aybars, A., \&Kutlu, O. (2010). Managing corporate performance: Investigating the relationship between corporate social responsibility and financial performance in emerging markets. International Journal of productivity and Performance management, 59(3), 229-254.

[7]. Armstrong, E. (2004). Globalization from below: AIDWA, foreign funding, and gendering anti-violence campaigns. Journal of Developing Societies, 20(1-2), 39-55.

[8]. Arteaga-Ortiz, J., \&Fernández-Ortiz, R. (2010). Why don't we use the same export barrier measurement scale? An empirical analysis in small and medium-sized enterprises.Journal of Small Business Management, 48(3), 395-420.

[9]. Awolusi, O. D. (2013). The effects of total quality management on customer service management in the Nigerian banking industry: an empirical analysis. International Journal of Management and Network Economics, 3(1), 57-77.

[10]. Ayanwale, A. B. (2007). FDI and economic Growth: Evidence from Nigeria.

[11]. Barney, J. (1991). Firm resources and sustained competitive advantage. Journal of management, 17(1), 99-120.

[12]. Barney, J. B. (1986). Strategic factor markets: Expectations, luck, and business strategy. Management science, 32(10), $1231-1241$.

[13]. Benigno, G., Converse, N., \& Fornaro, L. (2015). Large capital inflows, sectoral allocation, and economic performance. Journal of International Money and Finance, 55, 60-87.

[14]. Bevan, A. A., \&Estrin, S. (2000). The determinants of foreign direct investment in transition economies.

[15]. Bilkey, W. J., \&Tesar, G. (1977).The export behavior of smaller-sized Wisconsin manufacturing firms.Journal of international business studies, 8(1), 93-98. 
[16]. Brouthers, K. D., \&Brouthers, L. E. (2001).Explaining the national cultural distance paradox.Journal of International Business Studies, 32(1), 177-189.

[17]. Brouthers, K. D., \&Hennart, J. F. (2007). Boundaries of the firm: Insights from international entry mode research. Journal of management, 33(3), 395-425.

[18]. Buckley, P. J., \&Casson, M. (1976).A long-run theory of the multinational enterprise.In The future of the multinational enterprise (pp. 32-65). Palgrave Macmillan UK.

[19]. Buster, B. D. (2012). Relationship between Asset Allocation and Financial Performance of mutual funds in Kenya (Doctoral dissertation, University of Nairobi, Kenya).

[20]. Büthe, T., \& Milner, H. V. (2008). The politics of foreign direct investment into developing countries: increasing FDI through international trade agreements?.American Journal of Political Science, 52(4), 741-762.

[21]. Caballero, J. A. (2014). Do surges in international capital inflows influence the likelihood of banking crises?. The Economic Journal.

[22]. Campbell, K., \&Mínguez-Vera, A. (2008).Gender diversity in the boardroom and firm financial performance.Journal of business ethics, 83(3), 435-451.

[23]. Chang, D. S., \&Kuo, L. C. R. (2008). The effects of sustainable development on firms' financial performance-an empirical approach.Sustainable Development, 16(6), 365-380.

[24]. Cheng, L. K., \& Kwan, Y. K. (2000). What are the determinants of the location of foreign direct investment? The Chinese experience. Journal of international economics, 51(2), 379-400.

[25]. Chi, C. G., \&Gursoy, D. (2009). Employee satisfaction, customer satisfaction, and financial performance: An empirical examination. International Journal of Hospitality Management, 28(2), 245-253.

[26]. Coase, R. H. (1937). The nature of the firm.economica, 4(16), 386-405.

[27]. Czinkota, M. R. (1982). Export development strategies: US promotion policy. Praeger.

[28]. Damijan, J. P., Rojec, M., Majcen, B., \& Knell, M. (2013). Impact of firm heterogeneity on direct and spillover effects of FDI: Micro-evidence from ten transition countries. Journal of comparative economics, 41(3), 895-922.

[29]. Denisia, V. (2010). Foreign direct investment theories: An overview of the main FDI theories. European Journal of Interdisciplinary Studies, (3).

[30]. Doukas, J. A., \& Lang, L. H. (2003).Foreign direct investment, diversification and firm performance.Journal of International Business Studies, 34(2), 153-172.

[31]. Doytch, N., \&Uctum, M. (2011). Does the worldwide shift of FDI from manufacturing to services accelerate economic growth? A GMM estimation study.Journal of International Money and Finance, 30(3), 410-427.

[32]. Egbetokun, A., \&Siyanbola, W. (2011, June).Firm-level openness and innovation performance in Nigeria: An empirical exploration.In XXII ISPIM Conference, Hamburg (pp. 12-15).

[33]. Ehinomen, C., \& Daniel, O. O. (2012).Export and Economic Growth Nexus in Nigeria.Management Science and Engineering, 6(4), 132.

[34]. El-Higzi, F. (2002).Foreign Market Selection Factors in the Australian Construction Services Sector.The Australian Journal of Construction Economics and Building, 2(1), 107-120.

[35]. Ezeoha, A. (2007). Structural effects of banking industry consolidation in Nigeria: A review. Journal of banking regulation, 8(2), $159-176$.

[36]. Ezeoha, A. E. (2011). Banking consolidation, credit crisis and asset quality in a fragile banking system: Some evidence from Nigerian data. Journal of financial regulation and compliance, 19(1), 33-44.

[37]. Ezeoha, A., Ebele, O., \&NdiOkereke, O. (2009).Stock market development and private investment growth in Nigeria.Journal of Sustainable Development in Africa, 11(2), 20-35.

[38]. Falk, M. (2012).Quantile estimates of the impact of R\&D intensity on firm performance. Small Business Economics, 39(1), $19-37$.

[39]. Fernández, Z., \& Nieto, M. J. (2005). Internationalisation strategy of small and medium-sized family businesses: Some influential factors. Family Business Review, 18(1), 77-89. 